BANCO DE ESPAÑA

\title{
ON STOCK MARKET RETURNS AND RETURNS ON INVESTMENT
}

Fernando Restoy and G. Michael Rockinger 
BANCO DE ESPAÑA

\title{
ON STOCK MARKET RETURNS AND RETURNS ON INVESTMENT
}

\author{
Fernando Restoy and G. Michael Rockinger $\left({ }^{*}\right)$
}

(*) We are grateful to Gary Chamberlain, Greg Mankiw and Philippe Weil for comments. The first author is Senior Economist in the Research Department of the Bank of Spain. The second author is Assistant Professor at Groupe HEC; he wishes to acknowledge financial support from FNEGE.

\author{
SERVICIO DE ESTUDIOS
}

Documento de Trabajo n. ${ }^{\circ} 9311$ 
In publishing this series the Bank of Spain seeks to disseminate studies of interest that will help acquaint readers better with the Spanish economy.

The analyses, opinions and findings of these papers represent the views of their authors; they are not necessarily those of the Bank of Spain.

ISBN: 84-7793-219-0

Depósito legal: M-11906-1993

Imprenta del Banco de Espan̄a 


\begin{abstract}
This paper presents general conditions under which it is possible to obtain asset pricing relations from the intertemporal optimal investment decision of the firm. Under the assumption of linear homogeneous production and adjustment cost functions (the Hayashi (1982) conditions), it is possible to establish, state by state, the equality between the return on investment and the market return of the financial claims issued by the firm. This result proves to be, in essence, robust to the consideration of very general constraints on investment and the inclusion of taxes.
\end{abstract}




\section{INTRODUCTION}

Standard work in asset pricing relates the returns on financial claims with the intertemporal marginal rate of substitution of economic agents [e.g., Breeden (1979), Merton (1973), Lucas (1978), and Hansen and Singleton (1982)]. The intertemporal marginal rate of substitution typically involves a function of consumption growth. The empirical performance of this approach has not been very successful in explaining the relation between financial variables and the business cycle. On one hand, consumption is probably too smooth to explain the behavior of asset returns, and on the other hand, this variable is not an accurate proxy for economic activity.

Production variables such as investment and output, are relatively more volatile and more characteristic of economic fluctuations than consumption. Furthermore, studies by Fama and Gibbons (1982), Fama and French (1989), and Barro (1989) have documented a significant relation between stock returns and both output and investment. These facts seem to suggest that theoretical models which succeed in relating asset returns with production side variables might be empirically more successful.

Standard production based asset pricing models [e.g., Brock (1982), Sharatchandra (1990), and Braun (1990)] assume price-taking managers who maximize the net present discounted value of the firm in a world with complete markets. The first order conditions are stocbastic Euler equations which state that the conditional mean of returns on investment evaluated with contingent prices must be equal to a constant. Thus, as any return on a financial claim, investment returns have to satisfy a traditional Euler equation. However, contingent claim prices are not obtainable from standard specifications of the technology. It follows that, in general, the first order 
conditions of the optimization problem involve unobserved terms unless one is willing to assume a particular specification of the relative prices. This requires a particular specification for consumer preferences [as in Sharatchandra (1990) or Braun (1990)].

Research which attempts to further exploit the implications of the assumption of market completeness [as in Cochrane (1991)] is probably more promising. This assumption ensures that investment payoffs can be replicated with the existing financial claims. Cochrane assumes a particular technology and adjustment cost function which allows him to identify the replicating marketed portfolio with the return on the stock of the firm. In this paper we build on Cochrane's (1991) result and obtain a general set of conditions under which one can identify the portfolio which replicates the investment return with the return on the financial claims issued by the firm.

The structure of this paper is as follows. In section 2 we find that it is possible to obtain strong asset pricing implications when a model similar to the one used in $\mathrm{q}$-theory of investment is set in an uncertain environment. In particular we show that in a world with complete markets, the return on investing in a firm with linear homogeneous production and adjustment cost function [the Hayashi (1982) conditions] is equal state by state to the market return of a claim on the stock of the firm. In section 3 we extend the analysis to the case where the firm is constrained in its possibilities to raise external funds to finance investment and find a similar result to the one obtained in section 2. The expression of the investment return, though, is modified to incorporate a term which measures the binding character of the constraint. In section 4 , we focus on taxation and find that the investment return can be replicated by a portfolio composed by the stock of the firm and a risk free discount bond. Section 5 concludes. 


\section{THE BASIC MODEL}

Assume a standard multiperiod production economy under uncertainty. Trading takes place at discrete points of time indexed by $t=1,2, \cdots$. The resolution of uncertainty can be represented by an event tree. Assume that there exists a sufficient number of securities to dynamically complete the markets. Therefore, there exists a probability measure under which any (normalized) payoff structure must be priced as a conditional expectation to prevent arbitrage ${ }^{1}$ [e.g., Harrison and Kreps (1979), Huang and Litzenberger (1988)]. Denote the expectations operator under this alternative probability by $E^{*}$ and let $p_{t}, x_{t+1}$ denote the price of an asset and its random payoff. Assume without loss of generality the existence of an infinitely lived security with a strictly positive price at all times. Call $b_{t}$ the price at time $t$ of such a claim chosen as numeraire. Let $P_{t}=p_{t} / b_{t}, X_{t+1}=x_{t+1} / b_{t+1}$ be the normalized prices. Then the return $R_{t+1}=X_{t+1} / P_{t}$ has to satisfy the no arbitrage condition

$$
E_{t}^{*}\left\{R_{t+1}\right\}=1 \text {. }
$$

Consider now a representative firm under perfect competition. Let $k_{t}, i_{t}$ and $\lambda_{t}$ stand for the capital stock of the firm, investment and a random technical shock. The latter is assumed to be markovian; therefore future realizations depend on the past only through the present. Also assume that the distribution of the technical shock is independent of the existing capital stock and that it becomes observed at the beginning of each period. Define, for simplicity, a single factor production function $y_{t}=f\left(k_{t}\right) \lambda_{t}$ and a capital accumulation rule $k_{t+1}=a\left(k_{t}, i_{t}\right)$. Assume $f(\cdot)$ and $a(\cdot, \cdot)$ are continuously differentiable with strictly positive partial derivatives over their domains. The capital accumulation rule incorporates capital depreciation as

\footnotetext{
${ }^{1}$ This is sometimes called in the literature risk neutral pricing.
} 
well as installation costs ${ }^{2}$. For notational convenience we denote in capital letters the corresponding normalized variables in terms of the price of the infinitely lived security taken as numeraire. Therefore, define as $K_{t}=k_{t} / b_{t}, I_{t}=i_{t} / b_{t}, Y_{t}=y_{t} / b_{t}$, $F\left(K_{t}\right)=f\left(K_{t} b_{t}\right) / b_{t}$ and as $A\left(K_{t}, I_{t}\right)=a\left(K_{t} b_{t}, I_{t} b_{t}\right) / b_{t+1}$ the normalized capital stock, investment, output, production function and capital accumulation rule. Finally define the normalized cash flow as $D_{j}=F\left(K_{j}\right) \lambda_{j}-I_{j}$.

Under the assumption of efficient markets, the gross value at time $t$ of a firm is given by the expected present discounted value of the random stream of future cash fiows $\left\{D_{j}\right\}_{j=t+1}^{+\infty}$. More formally

$$
V_{t}=E_{t}^{*}\left\{\sum_{j=t+1}^{+\infty} D_{j}\right\}
$$

Define $J_{t} \equiv V_{t}-I_{t}$ as the net value of the firm at period $t$. Assume producers choose the investment path which maximizes the expected future stream of cash flows subject to a technological constraint. We can then write $\boldsymbol{J}_{t}$ as

$$
\begin{gathered}
J_{t}=\max _{\left\{I_{t}\right\}} E_{t}^{*}\left\{-I_{t}+\sum_{j=t+1}^{+\infty}\left[F\left(K_{j}\right) \lambda_{j}-I_{j}\right]\right\}, \\
\text { s.t. } \quad K_{t+1}=A\left(K_{t}, I_{t}\right) .
\end{gathered}
$$

As shown in Appendix A the first order conditions for the producer problem can be written as follows

$$
E_{t}^{*}\left\{\left[F_{K}\left(K_{t+1}\right) \lambda_{t+1}+\frac{A_{K}\left(K_{t+1}, I_{t+1}\right)}{A_{I}\left(K_{t+1}, I_{t+1}\right)}\right] A_{I}\left(K_{t}, I_{t}\right)\right\}=1
$$

Equation 4 states that along an optimal investment path it must be true that expected marginal benefits are equal to marginal costs. Notice that $1 / A_{I}\left(K_{t}, I_{t}\right)$ is

\footnotetext{
${ }^{2}$ For instance $k_{t+1}=(1-\delta) k_{t}+g\left(k_{t}, i_{t}\right) i_{t}$. Where $g(\cdot, \cdot)$ represent adjustment costs per unit of investment and $\delta$ is the depreciation rate of capital.
} 
the value (in terms of investment at period $t$ ) of a unit of capital installed during the next production period. This marginal unit of capital produces $F_{K}\left(K_{t+1}\right) \lambda_{t+1}$ units of the investment good at time $t+1$ but also depreciates into $A_{K}\left(K_{t+1}, I_{t+1}\right)$ units of capital ${ }^{3}$ which are worth $A_{K}\left(K_{t+1}, I_{t+1}\right) / A_{I}\left(K_{t+1}, I_{t+1}\right)$ units of investment at period $t+1$.

We can therefore define the investment return as

$$
R_{t+1}^{I} \equiv\left[F_{K}\left(K_{t+1}\right) \lambda_{t+1}+\frac{A_{K}\left(K_{t+1}, I_{t+1}\right)}{A_{I}\left(K_{t+1}, I_{t+1}\right)}\right] A_{I}\left(K_{t}, I_{t}\right)
$$

The first order condition for an optimal investment schedule (4) therefore implies that the investment return should satisfy an orthogonality condition analogous to (1)

$$
E_{t}^{*}\left\{R_{t+1}^{I}\right\}=1
$$

This expression states that the investment return has to satisfy as any other asset return a set of arbitrage conditions represented generically by (1). Expression (6) can be tested if the equivalent probability measure is specified. This approach (used implicitly by Sharatchandra (1990) and Braun (1990)) requires, however, the assumption of a particular preference structure to obtain explicit expressions for the contingent claim prices which define the new probabilities. It is also obvious that this approach is hardly a test of a new asset pricing theory.

However, the assumption of market completeness implies that the investment payoffs can be replicated by a portfolio of tradeable assets. Standard arbitrage arguments

\footnotetext{
${ }^{3}$ For the simplest case where there are no adjustment costs but exponential depreciation of capital we have $K_{t+1}=(1-\delta) K_{t}+I_{t}$ and in this case we obtain as first order condition

$$
E_{t}^{*}\left\{\left[F_{K}\left(K_{t+1}\right) \lambda_{t+1}+(1-\delta)\right]\right\}=1
$$

In this case the marginal unit of invested capital is worth its expected productivity plus its value after depreciation.
} 
then yield that the investment return should be equal state by state to the return of the replicating portfolio. A natural application of this idea is to relate the investment return of the firm with the return of the claims issued by the firm. Cochrane (1991) deals with a particular case where investment is perfectly replicated by the stock of the firm. Proposition 1 establishes general conditions under which the investment return is equal to the market return of the stock of the firm.

Let's define the market return of the firm as $R_{t+1}^{M}=\left(D_{t+1}+V_{t+1}\right) / V_{t}$. Then,

Proposition 1 If the production function and the capital accumulation rule are linear homogeneous then investment and market returns are equal state by state.

Proof Appendix A.

The equality result between investment and market returns ${ }^{4}$ requires exactly the Hayashi (1982) conditions to relate average and marginal valuations of the capital stock in a perfect foresight environment. A constant returns to scale production function is required since we do not want the firm to obtain quasirents beyond the remuneration to inputs. A linear homogeneous capital accumulation rule is required to ensure that the average market valuation of the installed capital is equal to the marginal one. Notice that in general, the stock market is evaluating the proceedings from owning an average unit of capital, while the investment return is related to the marginal unit of invested capital.

Proposition 1 shows how strong asset pricing implications can be derived from those technological conditions in a very general framework under uncertainty. Notice that the extension of this proposition to a multifactor technology is immediate. The definition of the investment return remains unchanged if the technology is assumed to include variable inputs together with the fixed input. Furthermore, the equality

\footnotetext{
${ }^{4}$ The conditions of this proposition are invariant to the adopted normalization. Also since the numerator and the denominator of investment and market returns involve terms with the same time subscript the equality state by state of the two returns also holds in the original units without normalization.
} 
between market and investment returns holds as long as it is assumed that firms are price takers in the factor markets and a complete set of contingent factor prices exist.

Cochrane (1991) obtains this result for a two-factor technology with endogenous marginal productivity of labor and capital. In proposition 1 it is seen how, not surprisningly, we can extend his finding for every technology that satisfies the Hayashi (1982) conditions. However, unlike Hayashi, we have assumed away taxation. On the other hand, like in most of Tobin's Q-literature, we have not included financing constraints.

In the next sections we investigate how extensions of the benchmark model affect the result stated in this section.

\section{CONSTRAINED INVESTMENT}

Asymmetric information and capital market imperfections provide explanations for the existence of limited possibilities of raising external funds to finance investment. The empirical investment literature [e.g., Fazzari, Hubbard and Petersen (1988) and Bronwyn H. Hall (1991)] has tried to incorporate financing constraints by including proxies of the liquidity status of the firm in a standard q-type of relation. However, this approach has failed to directly model the effects of those restrictions on the optimal investment decisions. Below we show how in our framework this issue can be modeled in a more satisfactory way for very general specifications of the financing constraints.

Assume that, at period $t$, the firm can only invest a proportion $\zeta_{t}\left(\lambda_{t}, t\right)$ of its capital stock. This seems to be a natural and sufficiently general way to account for the existence of financial rationing. 
The producer problem can therefore be written as

$$
\begin{gathered}
J_{t}=\max _{\left\{I_{t}\right\}} E_{t}^{*}\left\{-I_{t}+\sum_{j=t+1}^{+\infty}\left[F\left(K_{j}\right) \lambda_{j}-I_{j}\right]\right\} \\
\text { s.t. } \quad K_{t+1}=A\left(K_{t}, I_{t}\right) \\
I_{t} \leq \zeta_{t} K_{t} .
\end{gathered}
$$

To solve this program, we need to introduce a sequence of Lagrange multipliers $\gamma_{t}$ for the set of constraints (7). Those multipliers are set up to be nonnegative and zero if the constraint is not binding.

The first order conditions of the maximization problem (see Appendix A) imply the no arbitrage condition

$$
E_{t}^{*}\left\{R_{t+1}^{I}\right\}=1
$$

where the investment return $R_{t}^{I}$ is now defined as

$$
R_{t+1}^{I} \equiv\left[F_{K}\left(K_{t+1}\right) \lambda_{t+1}+\left(1+\gamma_{t+1}\right) \frac{A_{K}\left(K_{t+1}, I_{t+1}\right)}{A_{I}\left(K_{t+1}, I_{t+1}\right)}+\gamma_{t+1} \frac{I_{t+1}}{K_{t+1}}\right] \frac{A_{I}\left(K_{t}, I_{t}\right)}{\left(1+\gamma_{t}\right)}
$$

As before this equation states that along an optimal investment path marginal costs have to be equal to marginal expected benefits. If at period $t$ and period $t+1$ the firm is not liquidity constrained the investment return takes the same expression as seen in section 2. If the firm is constrained over time then there is an interplay of various factors which modify the expression of the investment return. First, if the constraint is binding at time $t$ every unit of installed capital at period $t+1$ is more valuable because feasible investment is below its optimal level at period $t$. The value of a unit of installed capital is therefore $\left(1+\gamma_{t}\right) / A_{I}\left(K_{t}, I_{t}\right)$. Second, at period $t+1$ the marginal unit of capital produces as before $F_{K}\left(K_{t+1}\right) \lambda_{t+1}$. Third, each unit of investment at period $t$ increases the capital stock at period $t+1$ and therefore relaxes the possibly binding character of the constraint at period $t+1$. This effect is measured by the 
term $\gamma_{t+1} I_{t+1} / K_{t+1}$. Fourth, every unit of remaining installed capital $A_{K}\left(K_{t+1}, I_{t+1}\right)$ has a higher value at $t+2$ if the constraint is binding at $t+1$. This is the explanation of the term $\left(1+\gamma_{t+1}\right) A_{K}\left(K_{t+1}, I_{t+1}\right) / A_{I}\left(K_{t+1}, I_{t+1}\right)$.

As in the basic model, under some technological conditions it is possible to link the return on the investment with the returns of a claim on the capital stock of the firm. As a first step, one can show that under the conditions of Proposition 1 the gross value of the firm can be expressed as

$$
V_{t}=\frac{\left(1+\gamma_{t}\right)}{a_{I}\left(K_{t}, I_{t}\right)} K_{t+1}
$$

This equation states that the market value of a claim to a capital stock of the firm is still proportional to its replacement cost. If the constraint is not binding, then the Lagrange multiplier is zero and the value of the firm is equal to the unconstrained case. If the constraint is binding then the Lagrange multiplier is positive. In this case, the desired investment is larger than the feasible investment and therefore the existing capital stock is more valuable. This gets translated into a greater shadow price of capital. Now we are ready to state the liquidity constrained version of Proposition 1.

PROPOSITION 2 If the production function and the capital accumulation rule are linear homogenous, then the investment return as defined by (8) is equal to market returns state by state.

PROOF Using the complementary slackness condition, the investment return for the general case (8) can be written as:

$$
R_{t+1}^{I} \equiv\left[F_{K}\left(K_{t+1}\right) \lambda_{t+1}+\left(1+\gamma_{t+1}\right) \frac{A_{K}\left(K_{t+1}, I_{t+1}\right)}{A_{I}\left(K_{t+1}, I_{t+1}\right)}+\gamma_{t+1} \zeta_{t+1}\right] \frac{A_{I}\left(K_{t}, I_{t}\right)}{\left(1+\gamma_{t}\right)}
$$

Multiplication of the numerator and denominator by $K_{t+1}$, using the Euler theorem 
for homogeneous functions and expression (9) yield

$$
\begin{aligned}
R_{t+1}^{I} & =\frac{F\left(K_{t+1}\right) \lambda_{t+1}+\left(1+\gamma_{t+1}\right) \frac{A_{K}\left(K_{t+1}, I_{t+1}\right)}{A_{I}\left(K_{t+1}, I_{t+1}\right)} K_{t+1}+\gamma_{t+1} \zeta_{t+1}}{\frac{K_{t+1}}{\left(1+\gamma_{t}\right)}} \\
& =\frac{f\left(K_{t+1}\right) \lambda_{t+1}-I_{t+1}+V_{t+1}}{V_{t}} \equiv R_{t+1}^{M} .
\end{aligned}
$$

One of the limitations of the model outlined in section 2 is the absence of taxes. In the following section we analyze how the relation between market and investment returns varies in presence of distortionary taxation. In particular, we modify the model to include taxation on corporate profits, and credits on investment expenditures and the depreciation of the capital stock.

\section{TAXES}

Let $u_{j}, k_{j}$ and $d(s, j-s)$ be respectively the corporate tax rate, the investment tax credit and a depreciation allowance for equipment of age $s$ at period $j$.

Therefore, total depreciation allowances at period $j$ are $d a_{j}=\sum_{s=1}^{+\infty} d(s, j-s) i_{j-s}$. As done in the previous sections, it is convenient to perform a normalization in units of an infinitely lived security by redefining $D A_{j}=d a_{j} / b_{j}$ and $D(s, j-s)=$ $d(s, j-s) b_{j-s} / b_{j}$. Under this renormalization, total depreciation allowances can be written

$$
D A_{j}=\sum_{s=1}^{+\infty} D(s, j-s) I_{j-s}
$$

The cash flows of the firm are given by after tax income minus investment expenditures adjusted for the investment tax credit plus depreciation allowances on existing 
capital

$$
D_{j}=\left[1-u_{j}\right] F\left(K_{j}\right)-\left\{1-k_{j}\right] I_{j}+u_{j} D A_{j}
$$

and the gross value of the firm can be expressed as

$$
V_{t}=E_{t}^{*}\left\{\sum_{j=t+1}^{+\infty}\left[1-u_{j}\right] F\left(K_{j}\right)-\left[1-k_{j}\right] I_{j}+u_{j} \sum_{s=1}^{+\infty} D(s, j-s) I_{j-s}\right\}
$$

Define for further use the following quantities

$$
\begin{aligned}
\alpha_{t} & \equiv \sum_{j=t+1}^{+\infty} z_{j} I_{j} \\
z_{t} & \equiv \sum_{s=1}^{+\infty} u_{t+s} D(s, t) \\
\beta_{t} & =\sum_{j=t+1}^{+\infty} \sum_{v=-\infty}^{t-1} D(j-v, v) I_{v}+z_{t} I_{t}
\end{aligned}
$$

then, the total amount of depreciation allowances can be split into two parts ${ }^{5}$ as follows

$$
\sum_{j=t+1}^{+\infty} u_{j} D A_{j}=\alpha_{t}+\beta_{t}
$$

The terms $\alpha_{t}$ and $\beta_{t}$ respectively measure the present discounted value of future depreciation allowances associated to future investment and existing capital at period $t+1$.

After some straightforward algebra analogous to the one indicated in appendix A, one can show that the first order conditions of the manager yield the standard no

\footnotetext{
${ }^{5}$ Similar results can be found in Hayashi (1982),Summers (1981), as well as Salinger and Summers (1983).
} 
arbitrage condition

$$
E_{t}^{*}\left\{R_{t}^{I}\right\}=1
$$

where the expression for investment return is

$$
R_{t}^{I} \equiv\left[\left[1-u_{t+1}\right] F_{K}\left(K_{t+1}\right) \lambda_{t+1}+\left(1-k_{t+1}-z_{t+1}\right) \frac{A_{K}\left(K_{t+1}, I_{t+1}\right)}{A_{I}\left(K_{t+1}, I_{t+1}\right)}\right] \frac{A_{I}\left(K_{t}, I_{t}\right)}{1-k_{t}-z_{t}}
$$

This expression is similar to the one given in section 1 . The only modification affects the relative price of invested capital at every period $t$. This variable now includes both the investment tax credit and the present discounted value of future depreciation allowances associated with this investment.

After tedious but straightforward manipulations it can be shown that (14) can be rewritten as

$$
R_{t}^{I}=\frac{D_{t+1}+V_{t+1}-\beta_{t}}{V_{t}-\beta_{t}}
$$

From this expression one can notice that the equality between investment and market return does not hold state by state. The latter incorporates the return of a depreciation bond whose face value is the present discounted value of future depreciation allowances associated with existing capital at period $t+1$. Notice that under the new probability measure the normalized riskless rate of return is zero.

However, we can easily obtain a replicating portfolio for the investment payoff.

\section{PROPOSITION 3}

Consider the following investment strategy: Buy the capital stock of the firm firm and shorten an amount $\beta_{t}$ of a riskfree discount bond. Then the investment return is equal to the return of this portfolio state by state.

\section{Proof}


Follows directly from expression (15) and the exclusion of arbitrage opportunities.

\section{Conclusion}

This paper presents general conditions under which it is possible to obtain asset pricing relations from the intertemporal optimal investment decision of the firm. The basic model places firms in an uncertain environment with complete markets. Under the assumption of linear homogeneous production and adjustment cost functions (the Hayashi (1982) conditions), it is possible to establish, state by state, the equality between the return on investment and the market return of the financial claims issued by the firm. This allows us to relate asset prices to technology without explicitly specifying discount factors or assuming the existence of a representative consumer. This result proves to be, in essence, robust to the consideration of very general constraints on investment and the inclusion of taxes. This paper places the findings of Cochrane (1991) in a general set-up and provides a fertile framework to obtain asset pricing implications from technological and financial characteristics of the firm. 


\section{APPENDIX A}

In this appendix we establish the link between the value of a firm and an optimal investment policy under uncertainty. Once we have stated the first order condition for optimal investment yielding the analytical expression for the investment return we will determine the value of the firm at any time. Finally we will establish that investment and market returns are equal state by state in this model. The problem defined by (3) can be written compactly in the following recursive manner

$$
J\left(K_{t}, \lambda_{t}\right)=\max _{\left\{I_{t}\right\}} E_{t}^{*}\left\{-I_{t}+F\left(A\left(K_{t}, I_{t}\right)\right) \lambda_{t+1}+J\left(A\left(K_{t}, I_{t}\right), \lambda_{t+1}\right)\right\} .
$$

The first order condition is at any time given by

$$
E_{t}^{*}\left\{\left[F_{K}\left(K_{t+1}\right) \lambda_{t+1}+J_{K}\left(K_{t+1}, \lambda_{t+1}\right)\right] A_{I}\left(K_{t}, I_{t}\right)\right\}=1
$$

Notice that since $K_{t}$ and $\lambda_{t}$ are the state variables it must be that investment is also a function of those variables. Along the optimal investment path combining the first order condition for optimality (16) as well as the capital accumulation rule yield the envelope condition

$$
J_{K}\left(K_{t+1}, \lambda_{t+1}\right)=\frac{A_{K}\left(K_{t+1}, I_{t+1}\right)}{A_{I}\left(K_{t+1}, I_{t+1}\right)}
$$

and therefore, the first order condition for optimal investment becomes

$$
E_{t}^{*}\left\{\left[F_{K}\left(K_{t+1}\right) \lambda_{t+1}+\frac{A_{K}\left(K_{t+1}, I_{t+1}\right)}{A_{I}\left(K_{t+1}, I_{t+1}\right)}\right] A_{I}\left(K_{t}, I_{t}\right)\right\}=1 .
$$

We are now ready to give the 
Proof of Proposition 1: Consider the experiment of multiplying $K_{t}$ and $I_{t}$ by some constant $\mu$. Then equation (17) becomes

$$
J_{K}\left(\mu K_{t+1}, \lambda_{t+1}\right)=\frac{A_{K}\left(K_{t+1}, I_{t+1}\right)}{A_{I}\left(K_{t+1}, I_{t+1}\right)}
$$

where we have used the assumption that $A$ is linear homogeneous and therefore that all partial derivatives depend only on the ratio $I_{t+1} / K_{t+1}$. Since $\mu$ appears only on the LHS of (19) it must be that the LHS does not depend on $K_{t+1}$.

Formally, we can therefore write that

$$
J_{K}\left(\lambda_{t+1}\right)=\frac{A_{K}\left(1, I_{t+1} / K_{t+1}\right)}{A_{I}\left(1, I_{t+1} / K_{t+1}\right)} \equiv H\left(\lambda_{t+1}\right) .
$$

Integration yields

$$
J\left(K_{t+1}, \lambda_{t+1}\right)=H\left(\lambda_{t+1}\right) K_{t+1}+h\left(\lambda_{t+1}, t+1\right) .
$$

Along an optimal investment path it must be that

$$
J\left(K_{t}, \lambda_{t}\right)=E_{t}^{*}\left\{-I_{t}+F\left(K_{t+1}\right) \lambda_{t+1}+J\left(K_{t+1}, \lambda_{t+1}\right)\right\}
$$

Substitution of (21) into (22) yields

$$
H\left(\lambda_{t}\right) K_{t}+h\left(\lambda_{t}, t\right)=E_{t}^{*}\left\{-I_{t}+F\left(K_{t+1}\right) \lambda_{t+1}+H\left(\lambda_{t+1}\right) K_{t+1}+h\left(\lambda_{t+1}, t+1\right)\right\} .
$$

The homogeneous solution of the integration $J\left(K_{t+1}, \lambda_{t+1}\right)=H\left(\lambda_{t+1}\right) K_{t+1}$ must satisfy equation (22). Indeed substitution in equation (22) and use of the linear homogeneity properties yields equation (16). From equation (23) we see therefore that $h$ 
has to satisfy the condition

$$
h\left(\lambda_{t}, t\right)=E_{t}^{*}\left\{h\left(\lambda_{t+1}, t+1\right)\right\}
$$

Notice that as long as we have not assumed a terminal condition for the Bellman equation, equation (24) admits an infinite number of solutions. However, assuming bubbles away, we only deal with the case where $h \equiv 0$ at all times.

By using again the assumption of homogeneity of $A$, we get along an optimal path that $V_{t} \equiv J_{t}-I_{t}=K_{t+1} / A_{I}\left(\lambda_{t}\right)$. This q-type of relation under uncertainty simply states that the value of the firm is proportional to the replacement value of its capital stock. The proportionality factor depends just on the realization of the technical shock. To finish the proof, recall that

$$
R_{t+1}^{I}=\frac{F_{K}\left(K_{t+1}\right) \lambda_{t+1}+\frac{A_{K}\left(K_{t+1}, I_{t+1}\right)}{A_{I}\left(K_{t+1}, I_{t+1}\right)}}{\frac{1}{A_{I}\left(K_{t}, I_{t}\right)}}
$$

then, multiplication and division by $K_{t+1}$ addition and subtraction of $I_{t+1}$ in the numerator as well as application of the Euler theorem for linear homogeneous functions yields

$$
\begin{aligned}
R_{t+1}^{I} & =\frac{F\left(K_{t+1}\right) \lambda_{t+1}-I_{t+1}+K_{t+2} / A_{I}\left(K_{t+1}, I_{t+1}\right)}{K_{t+1} / A_{I}\left(K_{t}, I_{t}\right)} \\
& =\frac{D_{t+1}+V_{t+1}}{V_{t}}=R_{t+1}^{M}
\end{aligned}
$$

This proof can be easily extended to situations where the investment is subject to explicit constraints. We indicate how to formulate the Bellrnan equation in terms of liquidity constraints $I_{t} \leq \zeta_{t} K_{t}$ but an analogous proof could be constructed for irreversible investment $I_{t} \geq 0$. Associate Lagrange multipliers $\gamma_{t}$ with the liquidity constraints $I_{t} \leq \zeta_{t} K_{t}$. Those Lagrange multipliers are subject to the complementary slackness condition $\gamma_{t}\left[\zeta_{t} K_{t}-I_{t}\right]=0$. 
The recursive structure of the optimization problem can then be written as

$$
J\left(K_{t}, \lambda_{t}\right)=\max _{\left\{I_{t}\right\}} E_{t}^{*}\left\{-I_{t}+F\left(K_{t+1}\right) \lambda_{t+1}+J\left(K_{t+1}, \lambda_{t+1}\right)+\gamma_{t}\left[\zeta_{t} K_{t}-I_{t}\right]\right\} .
$$

The remaining steps are similar to the ones outlined previously. 


\section{References}

ABEL, ANDREW , (1980), "Empirical Investment Equations: an Integrative Framework," in Carnegie Rochester Conference Series on Public Policy, Karl Brunner and Allan H. Meltzer eds., 12, 39-91.

Abel, Andrew B. And Olivier J. Blanchard , (1986) "The Present Value of Profits and Cyclical Movements in Investment," Econometrica, 54, 249-273.

BARro, Robert J. , (1989), "The Stock Market and Investment," manuscript, Harvard University, May.

Bertola, Giuseppe , (1989), "Irreversible Investment," manuscript, Princeton University.

Bertola, Giuseppe and Ricardo J. Caballero , (1990) "Irreversibility and Aggregate Investment," manuscript, Princeton University, June.

Blanchard, Olivier, Changyong Rhee and Lawrence Summers, ,(1990) "The Stock Market, Profit and Investment," manuscript, M.I.T., May.

Braun, Phillip A. , (1990), "Asset Pricing and Capital Investment: Theory and Evidence," manuscript, University of Chicago, November.

Breeden, D. , (1979), "An Intertemporal Capital Pricing Model with Stochastic Investment Opportunities," Journal of Financial Economics, pp. 265-296.

Brock, William A. , (1982), "Asset Prices in a Production Economy" in in John J. McCall (ed.), The Economics of Information and Uncertainty, Chicago: University of Chicago Press.

Brock, William A. and Blake LeBaron , (1989), "Liquidity Constraints In Production Based Asset Pricing Models," in R. Glenn Hubbard (ed.), Asymmetric Information, Corporate Finance, and Investment, Chicago: University of Chicago Press, 231-254. 
Cochrane, John H. , (1991), "Production-Based Asset Pricing and the Link Between Stock Returns and Economic Fluctuations," Journal of Finance, 46, 209-237.

Eisner, Robert and Robert H.Strotz , (1963), "Determinants of Business Investment", in Commission on Money and Credit Impacts of Monetary Policy, Englewood Cliffs, New Jersey: Prentice-Hall, pp. 59-337.

Fama, Eugene F. , (1990), "Stock Returns, Real Activity, Inflation and Money," American Economic Review, 71, 4, September, 545-565.

Fama, Eugene F. and Kenneth R. French , (1989), "Business Conditions and Expected Returns on Stocks and Bonds," Journal of Financial Economics, 25, pp. 23-49.

Fama, Eugene F. and Michael Gibbons , (1982), "Inflation, Real Returns, and Capital Investment," Journal of Monetary Economics, 13, 327-348.

Fazzari, Steven M., R. Glenn Hubbard and Bruce C. Petersen , (1988), "Financing Constraints and Corporate Investment," Brookings Papers of Economic Activity, $1,141-206$.

Gould, Joh N P. , (1968) "Adjustment Costs in the Theory of Investment of the Firm," Review of Economic Studies, 35, 47-55.

Hall, Bronwyn, H. , (1991), "Research and Development at the Firm Level: Does the Source of Financing Matter?" Department of Economics, Berkeley.

Hall, Robert E. and Dale W. Jorgenson , (1967) "Tax Policy and Investment Behavior," Americản Economic Review, 57, 391-413.

Hansen Lars Peter and Kenneth Singleton , (1982), "Generalized Instrumental Variables Estimation of Non-Linear Rational Expectations Models," Econometrica, 50, 1269-1286.

HAYAShi, Fumıo , (1982), “Tobin's Marginal q and Average q: A Neoclassical Interpretation," Econometrica, 50, 213-224. 
Hayashi, Fumio and Tohru Inoue, "The relation between firm growth and q with multiple capital goods: Theory and Evidence from panel Data on Japanese Firms," NBER Working Paper No. 3326.

Harrison, J. Michael and David Kreps , (1979), "Martingales and Arbitrage in Multiperiod Securities Markets," Journal of Economic Theory, 20, 381-408.

Huang, Chi-fu and Robert H. Litzenberger , (1988), "Foundations for Financial Economics," Elsevier Science Publishers, New York.

Lucas, Robert E. JR. , (1978), "Asset Prices in an Exchange Economy", Econometrica, $46,1426-1446$.

Lucas, Robert E. JR. and Edward C. Prescott , (1971), "Investment under Uncertainty," Econometrica, 39, 659-681.

Merton, Robert , (1973), "An Intertemporal Capital Asset Pricing Model," Econometrica, $41,867-887$.

PINDYCK, ROBERT , (1990), "Irreversibility, Uncertainty and Investment," NBER Working Paper No. 3307.

Pindyck, Robert S. and Julio J. Rotemberg , (1990), "The Comovement of Stock Prices," manuscript, MIT, July.

Restoy, F. ANd G. Michael Rockinger , (1991), "Investment Incentives in Endogenously Growing Economies," manuscript, Harvard University.

Salinger, Michael A. and Lawrence H. Summers , (1983), "Tax Reform and Corporate Investment: A Microeconometric Simulation Study, ${ }^{n}$ in Martin Feldstein (ed.) Behavioral Simulation Methods in Tax Policy Analysis, University of Chicago Press, $247-281$.

Sharatchandra, Gopalkrishnan , (1990), "An Asset Pricing Model with Production: Theory and Empirical Tests," manuscript, Southern Methodist University, June. 
Shiller, Robert J. , (1989), "Comovements in Stock Prices and Comovements in Dividends," Journal of Finance, 44, July, 719-729.

Stockey, Nancy L. and Robert E. Lucas, Jr. , (1989), "Recursive Methods in Economic Dynamics," Harvard University Press, Cambridge, Massachusetts.

Summers, Lawrence H. , (1981), "Taxation and Corporate Investment: A q-Theory Approach," Brooking Papers on Economic Activity, 67-140.

Treadway, Arthur B. , (1969), "On Rational Entrepreneurial Behavior and the Demand for Investment," Review of Economic Studies, 36, 227-239.

Uzawa, Hirofumi , (1969), "Time Preference and the Penrose Effect in a Two-Class Model of Economic Growth," Journal of Political Economy, 36, 227-240.

von Furstenberg, George M. , (1977), "Corporate Investment: Does Market Valuation Matter in the Aggregate?" Brooking Papers on Economic Activity, 2, 347-408.

Zeldes, Stephen P. , (1989), "Consumption and Liquidity Constraints: An Empirical Investigation," Journal of Political Economy, 97, 2, 305-346. 


\section{WORKING PAPERS (1)}

9201 Pedro Martínez Méndez: Tipos de interés, impuestos e inflación.

9202 Víctor García-Vaquero: Los fondos de inversión en España.

9203 César Alonso and Samuel Bentolila: The relationship between investment and tobin's Q in Spanish industrial firms. (The Spanish original of this publication has the same number.)

9204 Cristina Mazón: Márgenes de beneficio, eficiencia y poder de mercado en las empresas españolas.

9205 Cristina Mazón: El margen precio-coste marginal en la encuesta industrial: 1978-1988.

9206 Fernando Restoy: Intertemporal substitution, risk aversion and short term interest rates.

9207 Fernando Restoy: Optimal portfolio policies under time-dependent returns.

9208 Fernando Restoy and Georg Michael Rockinger: Investment incentives in endogenously growing economies.

9209 José M. González-Páramo, José M. Roldán y Miguel Sebastián: Cuestiones sobre política físcal en España.

9210 Ángel Serrat Tubert: Riesgo, especulación y cobertura en un mercado de futuros dinámico.

9211 Soledad Núñez Ramos: Fras, futuros y opciones sobre el MIBOR.

9212 Federico J. Sáez: El funcionamiento del mercado de deuda pública anotada en España.

9213 Javier Santillán: La idoneidad y asignación del ahorro mundial.

9214 María de los Llanos Matea: Contrastes de raíces unitarias para series mensuales. Una aplicación al IPC.

9215 Isabel Argimón, José Manuel González-Páramo y José María Roldán: Ahorro, riqueza y tipos de interés en España.

9216 Javier Azcárate Aguilar-Amat: La supervisión de los conglomerados financieros.

9217 Olympia Bover: An empirical model of house prices in Spain (1976-1991). (The Spanish original of this publication has the same number.)

9218 Jeroen J. M. Kremers, Neil R. Ericsson and Juan J. Dolado: The power of cointegration tests.

9219 Luis Julián Álvarez, Juan Carlos Delrieu and Javier Jareño: Treatment of conflictive forecasts: Efficient use of non-sample information. (The Spanish original of this publication has the same number.)

9220 Fernando C. Ballabriga y Miguel Sebastián: Déficit público y tipos de interés en la economía española: ¿existe evidencia de causalidad?

9221 Fernando Restoy: Interest rates and fiscal discipline in monetary unions. (The Spanish original of this publication has the same number.)

9222 Manuel Arellano: Introducción al análisis econométrico con datos de panel.

9223 Ángel Serrat: Diferenciales de tipos de interés onshore/offshore y operaciones swap.

9224 Ángel Serrat: Credibilidad y arbitraje de la peseta en el SME.

9225 Juan Ayuso and Fernando Restoy: Efficiency and risk premia in foreign exchange markets (The Spanish original of this publication has the same number.)

9226 Luis J. Álvarez, Juan C. Delrieu y Antoni Espasa: Aproximación lineal por tramos a comportamientos no lineales: estimación de señales de nivel y crecimiento.

9227 Ignacio Hernando y Javier Vallés: Productividad, estructura de mercado y situación financiera.

9228 Ángel Estrada García: Una función de consumo de bienes duraderos.

9229 Juan J. Dolado and Samuel Bentolila: Who are the insiders? Wage setting in spanish manufacturing firms.

9301 Emiliano González Mota: Políticas de estabilización y límites a la autonomía físcal en un área monetaria y económica común.

9302 Anindya Banerjee, Juan J. Dolado and Ricardo Mestre: On some simple tests for cointegration: the cost of simplicity.

9303 Juan Ayuso and Juan Luis Vega: Weighted monetary aggregates: The Spanish case. (The Spanish original of this publication has the same number.)

9304 Ángel Luis Gómez Jiménez: Indicadores de la política fĩscal: una aplicación al caso español.

9305 Ángel Estrada y Miguel Sebastián: Una serie de gasto en bienes de consumo duradero. 
9306 Jesús Briones, Ángel Estrada e Ignacio Hernando: Evaluación de los efectos de reformas en la imposición indirecta

9307 Juan Ayuso, María Pérez Jurado y Fernando Restoy: Indicadores de credibilidad de un régimen cambiario: el caso de la peseta en el SME.

9308 Cristina Mazón: Regularidades empíricas de las empresas industriales españolas: ¿existe correlación entre beneficios y participación?

9309 Juan Dolado, Alessandra Goria and Andrea Ichino: Immigration and growth in the host country.

9310 Amparo Ricardo Ricardo: Series históricas de contabilidad nacional y mercado de rabajo para la CE y EEUU: 1960-1991.

931] Fernando Restoy and G. Michael Rockinger: On stock market returns and returns on investment.

(1) Working Papers prior to 1992 are listed in Banco de España's publications catalogue.

Queries should be addressed to: Banco de España Sección de Publicaciones. Negociado de Distribución y Gestión Teléfono: 3385180

Alcalá, 50. 28014 Madrid 